\title{
Influenza B-related meningoencephalitis in adults
}

\author{
Chen Han Yong, ${ }^{1,2}$ Wilson Vallat, ${ }^{1}$ Graham Norton ${ }^{1}$
}

${ }^{1}$ Lyell McEwin Hospital, Elizabeth Vale, South Australia, Australia ${ }^{2}$ Faculty of Health and Medical Sciences, The University of Adelaide, Adelaide, South Australia, Australia

Correspondence to Dr Chen Han Yong, chenhan.yong108@gmail.com

Accepted 5 June 2018
Check for updates

To cite: Yong $\mathrm{CH}$, Vallat W, Norton G. BMJ Case Rep Published Online First: [please include Day Month Year]. doi:10.1136/bcr-2018 224960

\section{SUMMARY}

We present a case involving an 85-year-old man with acute confusion and new onset seizure following a 1-week history of respiratory prodrome. This case report describes a case of influenza B-related meningoencephalitis supported by evidence of an influenza B infection and temporal relation of the neurological event and respiratory illness in the absence of other identifiable cause. Diagnosis is guided by cerebrospinal fluid profile and nasopharyngeal $P C R$. Treatment is largely supportive and the effect of vaccination on prevention of this neurological complication remains unclear.

\section{BACKGROUND}

Influenza B-related meningoencephalitis is a less recognised entity with only few published articles in the literature thus far. While influenza A-associated encephalopathy especially is more widely described especially in paediatric population, influenza B-related meningoencephalitis is an important entity to recognise given the increasing influenza activity over recent years in Australia.

\section{CASE PRESENTATION}

An 85-year-old man was brought to hospital with acute confusion. This occurred following return from a cruise holiday trip to New Zealand 3 days prior during which he complained of having 1-week history of respiratory prodromal symptoms and fever. Background medical history was significant for moderate aortic stenosis and mild chronic obstructive airway disease without previous neurological condition.

On presentation, he was alert but was disorientated with a body temperature of 38.5 degrees Celsius. There was no neck stiffness or rash and examination was otherwise largely unremarkable. While initial work-up was being carried out, he developed two episodes of generalised tonic-clonic seizures. He required intubation with mechanical ventilation due to concern for airway compromise in the setting of reduced consciousness and was admitted to an intensive care unit.

\section{INVESTIGATIONS}

Initial investigations revealed mild leucopenia $\left(3.84 \times 10^{9} / \mathrm{L}\right)$, lymphocytopenia $\left(0.85 \times 10^{9} / \mathrm{L}\right)$ and $\mathrm{C}$ reactive protein of $40 \mathrm{mg} / \mathrm{L}$. Other tests including renal function, liver function tests and urine microbiology were normal. Viral PCR on nasopharyngeal swab tested positive for influenza B virus. Lumbar puncture on day 1 of admission revealed an elevated cerebrospinal fluid (CSF) protein of $2.15 \mathrm{~g} / \mathrm{L}$ with mononuclear cell pleocytosis $\left(35 \times 10^{6} / \mathrm{L}\right)$. Further CSF examination including bacterial, fungal and acid-fast bacilli was also negative. Viral PCR of CSF was negative for influenza virus.

MRI head with gadolinium series were performed, which showed generalised moderate atrophy including the medial temporal lobes.

\section{TREATMENT}

Aciclovir, which were given on presentation, were discontinued in light of the CSF viral PCR result. $\mathrm{He}$ was commenced on levetiracetam and sodium valproate with no further seizure activity since. In retrospect, given temporal relation of the neurological event and respiratory illness and failure in identifying other reversible causes, influenza B viral infection was thought to be the most likely explanation of lymphocytic meningoencephalitis.

\section{OUTCOME AND FOLLOW-UP}

His admission was complicated by slow neurological recovery due to severe encephalopathy, requiring extensive physiotherapy and occupational therapy involvement. He was transferred to the geriatrics department to undergo further restorative care.

\section{DISCUSSION}

The 2017 influenza season in Australia has recorded higher influenza-like illness (ILI) activity than recent years. This is supported by higher average general practitioner ILI consultation rate during the seasonal period (14.8 per 1000 consultations) compared with 5-year average for the period (10.3 per 1000 consultations). ${ }^{1}$ Influenza B was circulating at high levels and contributed $37 \%$ to the notifications of laboratory-confirmed influenza. ${ }^{1}$

Influenza $\mathrm{B}$ virus belongs to a family of RNA virus known as Orthomyxoviridae, which also include influenza $\mathrm{A}$ virus and influenza $\mathrm{C}$ virus. Influenza is an acute respiratory infection caused by influenza A or B virus, which occurs in outbreaks of varying extent every year. It usually begins abruptly with fever, myalgia, headache along with respiratory tract illness. Complications of influenza include pneumonia, myositis, myocarditis and neurological events including encephalitis as well as Guillain-Barre syndrome.

Influenza-associated encephalopathy is more common in children, usually in the setting of an influenza $\mathrm{A}$ infection. ${ }^{2}$ There are limited articles in the literature studying influenza B-related meningoencephalitis in adults. To the best of our knowledge, few published articles have specifically 
Unusual association of diseases/symptoms

\begin{tabular}{|c|c|c|c|c|c|c|}
\hline Authors & Sex/age (years) & Presentation & CSF & Imaging & Treatment & Outcome \\
\hline Hawkins et a $\left.\right|^{3}$ & $F / 37$ & $\begin{array}{l}\text { 2/7 Fever } \\
\text { Confusion } \\
\text { Neck stiffness } \\
\text { Status epilepticus }\end{array}$ & $\begin{array}{l}\text { Lymphocytes } \\
75 \times 10^{6} / \mathrm{L} \\
\text { Protein } \\
0.32 \mathrm{~g} / \mathrm{L} \\
\text { No virus }\end{array}$ & Normal CT head & $\begin{array}{l}\text { Dexamethasone } \\
\text { Anticonvulsant }\end{array}$ & $\begin{array}{l}\text { Complete resolution } \\
\text { after } 1 \text { year }\end{array}$ \\
\hline Jensen and Felding ${ }^{4}$ & $\begin{array}{l}\mathrm{F} / 30 \\
\text { Pregnant }\end{array}$ & $\begin{array}{l}\text { 1/7 Prodromal } \\
\text { Chills } \\
\text { Seizure } \\
\text { Disorientation }\end{array}$ & $\begin{array}{l}\text { Normal } \\
\text { No virus }\end{array}$ & $\begin{array}{l}\mathrm{CT} \text { head-diffuse oedema of } \\
\text { brain }\end{array}$ & Methylprednisolone & $\begin{array}{l}\text { Complete resolution } \\
\text { after } 10 \text { days }\end{array}$ \\
\hline \multirow[t]{2}{*}{ Ak et $a l^{5}$} & $F / 61$ & $\begin{array}{l}\text { 3/7 Fever } \\
\text { Rhinitis } \\
\text { Altered mental state }\end{array}$ & $\begin{array}{l}\text { No cells } \\
\text { Protein } \\
1.14 \mathrm{~g} / \mathrm{L}\end{array}$ & $\begin{array}{l}\text { Normal CT head } \\
\text { Normal MRI head }\end{array}$ & $\begin{array}{l}\text { Oseltamivir } \\
5 / 7\end{array}$ & $\begin{array}{l}\text { Complete resolution } \\
\text { after } 7 \text { days }\end{array}$ \\
\hline & $\mathrm{M} / 45$ & $\begin{array}{l}\text { 4/7 Fever Rhinorrhoea } \\
\text { Cough } \\
\text { Seizure }\end{array}$ & $\begin{array}{l}\text { No cells } \\
\text { Protein } \\
0.28 \mathrm{~g} / \mathrm{L}\end{array}$ & $\begin{array}{l}\text { Normal CT head } \\
\text { Normal MRI head }\end{array}$ & $\begin{array}{l}\text { Oseltamivir } \\
5 / 7\end{array}$ & $\begin{array}{l}\text { Complete resolution } \\
\text { after } 10 \text { days }\end{array}$ \\
\hline Popescu et al ${ }^{6}$ & $F / 27$ & $\begin{array}{l}3 / 7 \\
\text { Prodromal } \\
\text { Fever } \\
\text { Headache } \\
\text { Seizure } \\
\text { Coma }\end{array}$ & $\begin{array}{l}\text { Pleocytosis } \\
13 \times 10^{6} / \mathrm{L} \\
\text { Protein } \\
7.16 \mathrm{~g} / \mathrm{L}\end{array}$ & $\begin{array}{l}\text { Normal CT head } \\
\text { MRI head } \\
\text { Multiple areas of hyperintensities }\end{array}$ & $\begin{array}{l}\text { Methylprednisolone } \\
\text { Oseltamivir }\end{array}$ & Died in 3 days \\
\hline Bayer $^{7}$ & $\mathrm{M} / 41$ & $\begin{array}{l}\text { 3/7 Fever } \\
\text { Rhinitis } \\
\text { Confusion } \\
\text { Seizure }\end{array}$ & $\begin{array}{l}\text { Leucocyte } \\
21 \times 10^{6} / \mathrm{L} \\
\text { Protein } \\
0.54 \mathrm{~g} / \mathrm{L}\end{array}$ & $\begin{array}{l}\text { Normal CT head } \\
\text { Normal MRI head }\end{array}$ & Anticonvulsant & $\begin{array}{l}\text { Complete resolution } \\
\text { within } 1 \text { month }\end{array}$ \\
\hline
\end{tabular}

examined and discussed this less recognised entity. ${ }^{3-9}$ Table 1 illustrates the characteristics of influenza B-related encephalitis in patients for whom information is available. It is more common among women, with one patient reporting having previous history of Influenza A encephalitis. ${ }^{6}$ No clear predisposing factors were identified on review. Most patients involved in previous case reports were young to middle-aged individuals with no history of cognitive or intellectual impairment, while cerebral atrophy demonstrated on neuroimaging in our patient may have contributed to his prolonged neurological recovery as compared with previous cases.

Neurological symptom preceded by respiratory prodrome is a common theme among most reported cases. Patients usually suffer from prodromal features including fever and rhinorrhoea before developing deterioration in their neurological function. Generalised seizure activity has been reported in five patients while most patients developed altered mental state ranging from confusion to coma. A total of two patients required intubation due to comatose state. In our case, there was a clear 1-week history of respiratory prodromal illness prior to development of acute neurological symptoms characterised by confusion and generalised seizure activity.

Diagnosis may be difficult given that influenza viral RNA has rarely been detected in the CSF by PCR. ${ }^{2}$ Influenza B virus were detected through nasopharyngeal swab viral PCR or serum haemagglutination inhibition test. CSF samples in previous case reports were negative for influenza B virus, as in our patient. Meijer et al reported that influenza virus RNA in CSF was detected in $16 \%$ of cases, which may be explained by viral CSF concentrations of influenza virus being too low for detection by regular diagnostic tests. ${ }^{10}$ Otherwise, CSF may reveal lymphocytosis or raised protein, which was similar to our patient. Neuroimaging finding on MRI are largely non-specific in diagnosing influenza B-related meningoencephalitis but certainly has a role in ruling out other structural causes of neurological function decline.

Most patients from previous reports received course of oseltamivir. Antiviral therapy achieved complete resolution in symptoms over a shorter duration of time as compared with patients who did not receive this. Interestingly, two patients in the study by Popescu et al did not receive vaccination prior to neurological complications, ${ }^{6}$ while influenza vaccination was administered in our patient. Unfortunately, the vaccination status in patients with influenza-associated meningoencephalitis was not studied in other literature. Thus, it remains an area for future research to determine the effect of vaccination on neurological complication secondary to influenza infection.

\section{Learning points}

- Influenza B-related meningoencephalitis is an important entity to recognise given the increasing influenza activity.

- Neurological sequelae are usually preceded by respiratory prodromal illness.

- Diagnosis is guided by cerebrospinal fluid profile and nasopharyngeal PCR.

- Treatment with antiviral should be considered if other clear cause is not identified and there is no contraindication.

- Effect of vaccination on prevention neurological complication remains unclear.

Contributors CHY and WV wrote the manuscript. GN supervised the development of work and manuscript evaluation. 
Funding The authors have not declared a specific grant for this research from any funding agency in the public, commercial or not-for-profit sectors.

Competing interests None declared.

\section{Patient consent Obtained.}

Provenance and peer review Not commissioned; externally peer reviewed.

(c) BMJ Publishing Group Ltd (unless otherwise stated in the text of the article) 2018. All rights reserved. No commercial use is permitted unless otherwise expressly granted.

\section{REFERENCES}

1 National Influenza Surveillance Committee and Communicable Diseases Network Australia. Influenza season in Australia: a summary from the national influenza surveillance committee, 2017. 2017. http://www.health.gov.au/internet/main/ publishing.nsf/Content/cda-surveil-ozflu-flucurr.htm/\$File/2017-season-summary22112017.pdf (accessed Jan 2018).
2 Okuno H, Yahata Y, Tanaka-Taya K, et al. Characteristics and outcomes of influenzaassociated encephalopathy cases among children and adults in Japan, 2010-2015. Clin Infect Dis 2018;66:1831-7.

3 Hawkins SA, Lyttle JA, Connolly JH. Two cases of influenza B encephalitis. J Neurol Neurosurg Psychiatry 1987;50:1236-7.

4 Jensen LM, Felding C. Influenza B encephalitis in pregnancy. J Obstet Gynaecol 1990;10:530-1.

5 Ak Ö, Biteker F, Cag Y, et al. Influenza B-associated encephalopathy in two adults. J Infect Chemother 2012;18:961-4.

6 Popescu CP, Florescu SA, Lupulescu E, et al. Neurologic complications of influenza B virus infection in adults, Romania. Emerg Infect Dis 2017;23:574-81.

7 Bayer WH. Influenza B encephalitis. West J Med 1987;147:466.

8 Sivertsen B, Christensen PB. Acute encephalitis. Acta Neuro/ Scand 1996:93:156-9.

9 Leigh $A D$. Infections of the nervous system occurring during an epidemic of influenza B. Br Med J 1946:2:936-8

10 Meijer WJ, Linn FH, Wensing AM, et al. Acute influenza virus-associated encephalitis and encephalopathy in adults: a challenging diagnosis. JMM Case Rep 2016;3:e005076.

Copyright 2018 BMJ Publishing Group. All rights reserved. For permission to reuse any of this content visit http://group.bmj.com/group/rights-licensing/permissions.

BMJ Case Report Fellows may re-use this article for personal use and teaching without any further permission.

Become a Fellow of BMJ Case Reports today and you can:

- Submit as many cases as you like

- Enjoy fast sympathetic peer review and rapid publication of accepted articles

- Access all the published articles

Re-use any of the published material for personal use and teaching without further permission

For information on Institutional Fellowships contact consortiasales@bmjgroup.com

Visit casereports.bmj.com for more articles like this and to become a Fellow 